\title{
FACTORS AFFECTING QUALITY MANAGEMENT THROUGHOUT THE ORGANIZATION OF THE SUB-DISTRICT ADMINISTRATIVE ORGANIZATION
}

\author{
Niyom Suwandej
}

Suan Sunandha Rajabhat University, Bangkok, Thailand

The goal of this research was to study about quality management format across sub-district administrative organization by interview using structured in-depth questionnaires format as a tool for collecting data from executives and other managers in total of 125 people. The sample groups were specifically chosen from 10 of Khaerai Sub-district Administration Organization. Data were analyzed by using score from the questionnaires and findings a percentage of full score. The result showed the essential element of a concept idea in Quality management Format across the organization of SubDistrict administrative Organization namely 1) Leadership: 100 percent of executives and managers who had a good score in behavior or leading role affected to the organization. Leader had to know how to make idealistic and creative decision with a clear objective. A good leader had to work justly and be responsible when providing service and devote to the public that affect the whole society. 2) Training, 97.6 percent showed that there should be a training at least once a month. 92 percent gained more knowledge and understanding in particular topic from the training. 93.6 percent showed that the best and suitable training for organization was with tools or personal direct training emphasized on WALK Rally model and learning from the real situations. 3) Structure: there should have the direct command that supported service people. The practical organization should have to provide individual for the right job with effective communication. 4) Communication: Crucial to organization and service. That drove the management forward and acted as a tool to future success. 5) Rewarding: 100 percent result showed that there should be rewarding criterion or request for employees who showed diligence, endurance, and responsibility to one's duty 6) Evaluation process affected 96 percent of the service and organization development in improving working potential of the organization In conclusion, executives and manager of Khaerai Sub-district Administration Organization commented and proposed on the 6 main element of Quality management Format across Sub-District Administrative Organization have the highest score in the questionnaire.

Keywords: management; quality management; human resources; Thailand

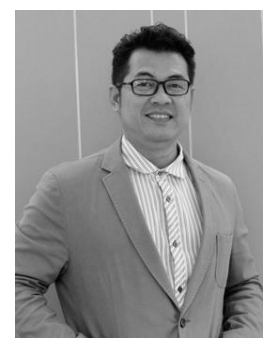

\section{Niyom Suwandej}

Doctor of Philosophy (Innovation Management), Suan Sunandha Rajabhat University Lecturer in College of innovation management, Suan Sunandha Rajabhat University, Bangkok, Thailand

Research interests: management, innovation management, human research management

Website : http://www.elcim.ssru.ac.th/niyom_su

E-mail : niyom.su@ssru.ac.th 


\section{FACTORS AFFECTING QUALITY MANAGEMENT}

\section{Introduction}

In contexts of management in 21 st century, information technology system growth rapidly, when compared with management in 20th century so the organization.

Nowadays had to adjust of change and to be able create the competitive advantage always as a result the government state and private sector were necessary to find the pattern or modern technology to lead their organization trough management excellent by the organization could be survived and growth in high competitive situation as a result the private and government state had alert to innovate bureaucracy to be advance in technology and new management innovation which were reformed bureaucracy in term of development as management in state to alert and aware in the key reorganization behavior and working process of bureaucracy to be suitable with context change.

For the organization was Thai government state gad encouraged in term of quality development and service. Office the Public Sector Development Commission (OPDC) had the follow up and assessment to duce the operation process and time in all government state sectors together, to hole the quality award of service by announcement reputation and enhanced moral and power of operator in order to motivate for other government state sectors as a result to concentrate and quality improvement of service to be good beside increased the core competency in operation of government state sector in quality and rising creditable of population as well.

The important approach of strategic of Thai bureaucracy development (B.E> 20032007) specified quality management of service by improving process and hoe to work in order to rise the core competency and working reference in this sector to be high level equivalent to international standard by good governance and the key feature of quality management components 3 reasons such as 1) Result-oriented 2) Able to apply on the mission of agency 3 ). There was linked and related with criteria to achieve integration so the indicated result of each those parts was communication tool and fundamental to practice consistent approach in whole government sector and supporting an innovation agility and authority diversity in decision additional enhancing core competency of quality in government sector also rising creditable population by 7 categories for instance

1). Leadership

2). Strategic planning and strategy

3). Focus on customer and stakeholder

4). Analysis measurement and knowledge management

5). Focus on human resource

6). Process management and

7). Operation result.

Office of the Public Sector Development Commission had tool Public Sector Management Quality Award or PMQA which was key performance indicator that was the international indicator assessment framework in addition it was self-assessment guideline and norm to follow and managing assessment of government sector in order to improve organization and quality management to international standard. 


\section{Literature review}

New Public Management (NPM) is a public sector reform agenda that was implemented during the late 1970s-1980s, which was the period when there was chaos in the world's economy. Western welfare states had high management costs but lacked efficiency. Furthermore, neoliberalism played a more prominent role and there was a change in the government's role in the West. During the Cold War, government agencies expanded extensively and were criticized for centralized administration, inefficiency, and unresponsiveness to changing environments. This failure directly resulted from the excessive role of government in public services (Baimyrzaeva, 2012).

NPM is a resistance to the traditional bureaucracy and big government. It emphasizes business approaches where management is a key skill, and the market and incentives are key mechanisms (Pollitt \& Bouckaert, 2011). Hood (1991) explained that key characteristics of NPM consist of hand-on professional management in the public sector, explicit standards and measures of performance, greater emphasis on output control, a shift to disaggregation of units in the public sector, a shift to greater competition, and stress on greater discipline and parsimony in resource use. Borins (1995 as cited in Borins, 2002, pp. 181e194), on the other hand, explained that NPM is characterized by: 1) high quality services; 2) measuring and rewarding for the improvement of the organization and individual perfor-mance; 3) promoting managerial autonomy, particularly reducing control by central agencies; 4) greater emphasis on performance targets; and 5) open-for-service competition.

Haque (2007) proposed that NPM consists of: 1) reduction of the public sector's direct role as a facilitator and implementation of the private sector in service de-livery through means such as downsizing, and outsourcing partnerships; 2) restructuring of the public sector with performance contracts as tools; 3) expansion of operational autonomy and flexibility in personnel and financial management through the establishment of autonomous agencies; 4) assessment of public sector performance by results rather than input or process; and 5) reinforcement of customer orientation by giving more customer choices, based on the benefits of customers. In brief, NPM is a reduction of the public sector's roles and allowing the private sector to take over in some service delivery areas with stress on administrative flexibility, target setting, and performance assessment, with fewer rules and regulations.

The implementation of NPM in Thailand was not obvious until the Sixth-Ninth National Economic and Social Development Plans, where the public sector's role changed from directing and assessing to monitoring.

The private sector was hired to work with public enterprises. In the meantime, the government policy NPM was promoted from General Chatchai Choonhavan's government (1988-1991) until Thaksin Shinawatra's government (2001-2006). Also, all the three Strategic Development Plans, namely the Bureaucracy Reform Model Scheme 1997-2001, the Public Sector Management Plan 1999, and the Thai Bureaucracy Strategic Development Plan 2001-2007, are based on NPM.

The concrete evidence of bureaucratic development based on NPM are the autonomous public organizations according to Thailand's International Public Sector Standard Management System and Outcomes (P.S.O), Result- based Management (RBM), Performance Agreement (PA), public sector management quality award (PMQA), eGovernment, Government Fiscal Management Information System (GFMIS) and Privatization. 


\section{FACTORS AFFECTING QUALITY MANAGEMENT}

In particular, in the government of Thaksin Shinawatra, there was a revision of the Public Administration Act 2002 and establishment of the Office of the Public Sector Development Commission (OPDC) to launch public sector development.

There was also a Royal Decree on Criteria and Procedures for Good Governance 2003 which served as a development plan that obligated all agencies to take action. Haque (2007) also suggested that Thailand's implementation of NMP occurred under the Public Administration Act 1992, Public Sector Management Re-form Plan 1999, and Result-based Budgets, and that PA is a widely popular tool of NPM. However, the investigation by Painter (2006) and Mongkol (2012) revealed that the development results related to NPM were cemented in the Thaksin government (2001-2006). In summary, Thailand employed management tools under NPM, especially by establishing public organizations, promoting information technology, and implementing PA effects on the extensive public sector.

\section{Methodology}

The data were collected through the research method used qualitative research and quantitative research sub-district administrative organization for 10 areas by sampling from managing level and head of functions for 125 people as 1) Quantitative research by the Questionnaires and Open-ended questionnaires 2) Qualitative research by the In-Depth interview

The data analysis, this research study in this work used in-depth interview that was the tool to collect data after getting the data from interview then taking those data to analyze to find the operation principle of sub-district administrative organization and relation included recommendation and found the guideline of creation factors affected quality management throughout the organization of the sub-district administrative organization.

\section{Result}

In this study, we performed on Khaerai Sub-district Administration Organization for 10 areas by sampling managing level and head of functions for 125 people. The result of study are consist of Factors affecting quality management throughout the organization of the subdistrict administrative organization in to be summary as follow;

Data analysis result that the Leadership Sector findings leadership factors were presented high level in table 1. It was found that Behavior or context of excellent leadership impacted organization development so the excellent leadership had to know making decision, thinking doing, philosophy, clear target had frequency as 125 percentage 100 and leadership referred the corrective principle had frequency 125 percentage 100, Leadership should operate about the responsible for society in case of service and impacted society in term of operation, listening other opinions, ready to improve immediately frequency of 125 percentage 100, Leadership should operate about the responsible for society in case of service and impacted society in term of operation, listening other opinions, ready to improve immediately frequency of 125 percentage 100, Qualifies of excellent leadership who was suitable with organization management should be making decisive decision thinking and doing frequency for 125 percentage 100 . 
Table 1. Leadership Sector able to conclude below

(Source: made by the author)

\begin{tabular}{|c|c|c|}
\hline Leadership Sector & $\begin{array}{c}\text { Frequency } \\
(\mathrm{n}=125)\end{array}$ & Percentage \\
\hline 1). Leadership & & \\
\hline $\begin{array}{l}\text { 1.1 Behavior or context of excellent leadership impacted } \\
\text { organization development so the excellent leadership had to } \\
\text { know making decision, thinking doing, philosophy, clear } \\
\text { target }\end{array}$ & 125 & 100 \\
\hline 1.2 Leadership referred the corrective principle & 125 & 100 \\
\hline $\begin{array}{l}\text { 1.3 Leadership should operate about the responsible for } \\
\text { society in case of service and impacted society in term of } \\
\text { operation, listening other opinions, ready to improve } \\
\text { immediately }\end{array}$ & 125 & 100 \\
\hline $\begin{array}{l}\text { 1.4 To find how to solve problem, making social understand } \\
\text { and know the problem happened }\end{array}$ & 102 & 81.6 \\
\hline $\begin{array}{l}1.5 \text { Management focused on human and job were important } \\
\text { for management in organization and model of human } \\
\text { management }\end{array}$ & 125 & 100 \\
\hline 1.6 The job should be suitable with ability of each person & 125 & 100 \\
\hline 1.7 The both of human and job had to go together & 111 & 88.8 \\
\hline $\begin{array}{l}\text { 1.8 Qualifies of excellent leadership who was suitable with } \\
\text { organization management should be making decisive } \\
\text { decision thinking and doing }\end{array}$ & 125 & 100 \\
\hline $\begin{array}{l}\text { 1.9 By there was clear target, standing point view, enjoin to } \\
\text { work }\end{array}$ & 123 & 98.4 \\
\hline 1.10 There was experience & 119 & 95.2 \\
\hline
\end{tabular}

Table 2. Training able to conclude below

(Source: made by the author)

\begin{tabular}{|c|c|c|}
\hline Training Sector & $\begin{array}{r}\text { Frequency } \\
(\mathrm{n}=125)\end{array}$ & Percentage \\
\hline 2). Training & & \\
\hline $\begin{array}{l}2.1 \text { Organization got the benefit from training so it should } \\
\text { be held training once a month }\end{array}$ & 122 & 97.6 \\
\hline $\begin{array}{l}2.2 \text { Getting the knowledge and more understand in the } \\
\text { subject of training }\end{array}$ & 115 & 86.4 \\
\hline $\begin{array}{l}2.3 \text { The best training which was suitable with organization } \\
\text { should be leaning by tool and personal directly }\end{array}$ & 117 & 93.6 \\
\hline 2.4 The emphasize training patter as walk rally feature & 84 & 67.2 \\
\hline 2.5 Leaning from tool real situation simulation & 68 & 54.4 \\
\hline $\begin{array}{l}\text { 2.6 Held training impacted organization development and } \\
\text { activities to be training for officer in organization in order to } \\
\text { more working effective }\end{array}$ & 125 & 100 \\
\hline 2.7 There was lecture to lecture & 125 & 100 \\
\hline 2.8 Taking knowledge to develop the job highest benefit & 99 & 79.2 \\
\hline
\end{tabular}

Tab. 2 showed the significance of the Training Sector factors. The findings revealed that factor high level were held training impacted organization development and activities to be training for officer in organization in order to more working effective frequency 125 percentage 100, there was lecture to lecture frequency 125 percentage 100 
FACTORS AFFECTING QUALITY MANAGEMENT

Table 3: Organization chart concluded as follow

(Source: made by the author)

\begin{tabular}{|c|c|c|}
\hline Organization chart Sector & $\begin{array}{l}\text { Frequency } \\
(\mathrm{n}=125)\end{array}$ & Percentage \\
\hline 3). Organization chart & & \\
\hline 3.1Organization had the small featured & 97 & 77.6 \\
\hline 3.2 The advantage of hierarchy & 125 & 100 \\
\hline 3.3 The disadvantages were not enough person to operate & 125 & 100 \\
\hline $\begin{array}{l}3.4 \text { Organization chart was suitable because it was easy to } \\
\text { control }\end{array}$ & 112 & 89.6 \\
\hline $\begin{array}{l}3.5 \text { specified organization chart impacted the convenience } \\
\text { for service and reaching of population, if it had complex } \\
\text { organization chart, it become delay service }\end{array}$ & 105 & 84 \\
\hline $\begin{array}{l}\text { 3.6 Excellent organization chart and optimal were applied in } \\
\text { management organization could distribute job to be suitable } \\
\text { with personal's ability }\end{array}$ & 125 & 100 \\
\hline $\begin{array}{l}3.7 \text { There had to flexible and convenience communication } \\
\text { system }\end{array}$ & 120 & 96 \\
\hline $\begin{array}{l}3.8 \text { Organization chart change impacted operation and } \\
\text { chartings as adaptation from sup-district administrative } \\
\text { organization to municipality }\end{array}$ & 125 & 100 \\
\hline 3.9 A might depend on the situation & 96 & 76.8 \\
\hline
\end{tabular}

Table 4. Communication could summarize as follow

(Source: made by the author)

\begin{tabular}{|c|c|c|}
\hline Communication Sector & $\begin{array}{c}\text { Frequency } \\
(\mathrm{n}=125)\end{array}$ & Percentage \\
\hline $\begin{array}{l}\text { 4). Communication } \\
\text { 4.1 Communication was important to organization and } \\
\text { service because operation management in the future } \\
\text { 4.2 The communication was tools to be successful } \\
4.3 \text { To impact the objective } \\
\text { 4.4 Factor was barrier of communication cause the service } \\
\text { problem so the organization should solve problem by to find } \\
\text { the roots cause } \\
4.5 \text { not clear document draft } \\
4.6 \text { And delay of document } \\
4.6 \text { Whatever factor was booting and supporting the } \\
\text { communication in organization effective to be the modern } \\
\text { technology such as internet } \\
4.7 \text { Communication system was most suitable for implement } \\
\text { in organization development, it should had the feature as it } \\
\text { could help the operation to be comfortable more } \\
4.8 \text { able to get the real benefit } \\
4.9 \text { and modern communication }\end{array}$ & $\begin{array}{c}99 \\
81 \\
117 \\
\\
113 \\
\\
99 \\
85\end{array}$ & $\begin{array}{c}79.2 \\
64.2 \\
77.6 \\
\\
90.4 \\
\\
79.2 \\
68\end{array}$ \\
\hline
\end{tabular}

Tab. 3 showed the significance of the Organization chart Sector factors. The findings revealed that factor high level were the advantage of hierarchy frequency for 125 percentage 100 and disadvantages was not enough person to operate frequency for 125 percentage 100 , Excellent organization chart and optimal were applied in management organization could distribute job to be suitable with personal's ability frequency for 125 percentage 100, 
Organization chart change impacted operation and chartings as adaptation from sup-district administrative organization to municipality had frequency for percentage 100 .

Table 5. Reward could conclude as follow

(Source: made by the author)

\begin{tabular}{|l|c|c|}
\hline \multicolumn{1}{|c|}{ Reward Sector } & $\begin{array}{c}\text { Frequency } \\
\text { (n=125) }\end{array}$ & Percentage \\
\hline 5). Reward & 125 \\
5.1 It should have the regulation and principal to give the \\
reward for officer such as diligence, patience and \\
responsible for duty
\end{tabular}

Tab. 4 showed the significance of the Organization chart Sector factors. The findings revealed that factor high level were communication was important to organization and service because operation management in the future had frequency for 125 percentage 100 and communication was tools to be successful had frequency for 125 percentage 100 . The findings revealed that Reward Sector factor high level were it should have the regulation and principal to give the reward for officer such as diligence, patience and responsible for duty frequency for 125 percentage 100 shown in tab 5 .

Tab. 6 showed the significance of the Organization chart Sector factors. The findings revealed that factor high level were results from measurement and assessment the performance could take the benefit to develop the service of organization so it become learning and development had frequency for 125 percentage 100, organization had taken the information technology system to take in measurement and assessment and impacted organization management besides modernization found that it made to know the organization development guideline In the future had frequency for 125 percentage 100.

The findings revealed that Teamwork Sector factor high level were Teamwork impacted to organization to be able that successful. Excellent teamwork was suitable have to feature teamwork member open relation and honest had frequency for 115 percentage 92, organization focused on the teamwork found that sup-district administrative organization was the service job. Team was important to service had frequency for 114 percentage 91.2 and Teamwork development guideline had potential. Excellent teamwork impact organization development found that there was always specified meeting had frequency for 111 percentage 88.8 shown in table 7 . 


\section{FACTORS AFFECTING QUALITY MANAGEMENT}

Table 6. Measurement and assessment could conclude as follow

(Source: made by the author)

\begin{tabular}{|c|c|c|}
\hline Measurement and assessment Sector & $\begin{array}{c}\text { Frequency } \\
(\mathrm{n}=125)\end{array}$ & Percentage \\
\hline 6). Measurement and assessment & & \\
\hline $\begin{array}{l}6.1 \text { Assessment impacted to operation of service and } \\
\text { organization development and it had boot working high } \\
\text { potential of organization }\end{array}$ & 120 & 96 \\
\hline 6.2 motivation was the officer development their ability & 97 & 77.6 \\
\hline $\begin{array}{l}\text { 6.3 Organization was confidence that measurement and } \\
\text { assessment system was sensitive to change and current } \\
\text { event and measurement system change was sensitive to } \\
\text { current situation by service of unit was necessary to } \\
\text { competitive with other organization so there was not the tool } \\
\text { to measure and assess }\end{array}$ & 79 & 63.2 \\
\hline $\begin{array}{l}6.4 \text { There was feature that it was not mention the profit so it } \\
\text { was not necessary to have the modern tool to measure and } \\
\text { assess }\end{array}$ & 62 & 49.6 \\
\hline $\begin{array}{l}6.5 \text { Excellent measurement and assessment should have } \\
\text { officer to assess who had the knowledge and understand the } \\
\text { assessment system }\end{array}$ & 57 & 45.6 \\
\hline $\begin{array}{l}\text { 6.6 Results from measurement and assessment the } \\
\text { performance could take the benefit to develop the service of } \\
\text { organization so it become learning and development }\end{array}$ & 125 & 100 \\
\hline 6.7 It made potential the operation of organization & 109 & 87.2 \\
\hline 6.8 It was the guideline to solve problem from root cause & 99 & 79.2 \\
\hline $\begin{array}{l}6.9 \text { Organization had taken the information technology } \\
\text { system to take in measurement and assessment and } \\
\text { impacted organization management besides modernization } \\
\text { found that it made to know the organization development } \\
\text { guideline in the future }\end{array}$ & 125 & 100 \\
\hline 6.10 It made to know the potential level of service & 109 & 87.2 \\
\hline $\begin{array}{l}6.11 \text { It was to show the personnel's ability in service job } \\
\text { how many their ability }\end{array}$ & 79 & 63.2 \\
\hline
\end{tabular}

\section{Conclusions and Discussion}

Factors affected quality management throughout the organization of the sub-district administrative organization separated consideration for 7 sector by interview which was tool of collaged data from managing level and leader of other functions total 125 persons by purposive sampling of sub-district administrative organization in Khaerai Sub-district Administration Organization for 10 areas found that

1. Leadership, managing and leader of other functions percentage 100 had the score of behavior and context of excellent leadership impacted organization had to know making decisive decision, thinking, doing, philosophy and clear goal at the same time excellent leadership depended leadership principle in leadership who should be responsible for social. In case of the operation impacted social and listening opinion of others and ready to take it improve promptly and to find how to solve problem happened in order to make in understand and know the problem happened. Administration should focus both person and job so administration in organization both person and job management model should assign to each ability and quality of excellent leadership and there was suitable to admin the job in organization to be feature as making decision, thinking, doing clear goal and enjoin to work related with Hersey and Banchard (1982) found that leadership was effective who should 
have self-confident to working in any job and there was knowledge and competency in their job and related with border Tanaporn and Mathani Sadudi (2000) said that the result of excellent leadership made good participation of person, working with moral, quality of job, creativity and responsibility together so to create excellent leadership trough good participation in activities

Table 7. Teamwork was the team able to conclude as follow (Source: made by the author)

\begin{tabular}{|c|c|c|}
\hline Teamwork Sector & $\begin{array}{c}\text { Frequency } \\
(\mathrm{n}=125)\end{array}$ & Percentage \\
\hline $\begin{array}{l}\text { 7). Teamwork } \\
\text { 7.1 Organization focused on the teamwork found that sup- } \\
\text { district administrative organization was the service job. } \\
\text { Team was important to service } \\
\text { 7.2 And teamwork was the important factor to impact the } \\
\text { organization successful } \\
\text { 7.3 Teamwork development guideline had potential. } \\
\text { Excellent teamwork impact organization development found } \\
\text { that there was always specified meeting } \\
\text { 7.4 Giving time to each other } \\
\text { 7.5 And there was specified the principle } \\
\text { 7.6 Organization successful, the most focused on the } \\
\text { teamwork management and organization had job } \\
\text { management model should be applied, found the reason had } \\
\text { nobody able to work alone so teamwork should have a role } \\
\text { on all function } \\
\text { 7.7 And service was the main role of sup-district } \\
\text { administrative organization and teamwork was the factor } \\
\text { impacted job achievement } \\
\text { 7.8 Teamwork impacted to organization to be able that } \\
\text { successful. Excellent teamwork was suitable have to feature } \\
\text { teamwork member open relation and honest } \\
\text { 7.9 And member of team had understood in target clearly } \\
\text { 7.10 Teamwork had to use time for assessment of team to } \\
\text { solve the weakness of working }\end{array}$ & $\begin{array}{c}53 \\
115 \\
100 \\
6\end{array}$ & $\begin{array}{c}42.2 \\
92 \\
\\
80 \\
52.8\end{array}$ \\
\hline
\end{tabular}

2. Training should have training at least once a month percentage 97.6 got more knowledge and understand in training percentage 92, excellent training process was suitable with organization found that leaning from tool or personal directly percentage 93.6 and emphasized training pattern was feature walk rally. Training impacted the organization development in term of seminar, lecture and lecturer made more effective percentage 100 related with the research of (Kelly,2001) turn to develop job to be highest benefit become more effective and expertise included officer changed the behavior to operate in organization demand direction, love and unity in organization (Chance,2003) included lecture in academe knowledge, speculation, interested in and wanted to know, up to date, modernized innovation, working technology to be process, there was vision and system impacted training participants had knowledge and quick understand and learning

3. Organization chart the advantage of certain hierarchy and disadvantage was there was not enough person to operate percentage 100 means suitable Organization because it was easy to control percentage 89.6. Specified structure impacted the convenience of service and reached population, if organization chart had complex, it affected delay of service 


\section{FACTORS AFFECTING QUALITY MANAGEMENT}

percentage 84, suitable organization chart was applied administration in organization had to divide each person 's ability percentage 100, there was flexible and convenience communication system percentage 96, changed structure of organization affected operation such as adjustment from " sub-district administrative organization " to municipality percentage 100 would impact depended on situation percentage 76.8 which related with research of Macfarlane (1974) said that fundamental of organization chart arrangement had to be suitable with some job to assigned by their ability $\mathrm{f}$ each person to be suitable and flexible in order to organization cloud operate successful through. Comras Naranan and Prateep Trakulsa (2013) studied administration of sub-district administrative organization of Thaloung sub-district, Muang district, Phichit province separated by 7 parts such as organization chart, value of organization, administration pattern, skill, knowledge, core competency, personal, strategy and operation system of organization found that management of sub-district administrative organization not depended on news recognition and management sub-district administrative organization depended on age, education, salary, position and career significantly.

4. Communication was important to organization and service, it made the next administration and successful tool percentage 100 impacted to objective percentage 84.8 and cloudy document percentage 79.2 Factor was booting or supporting the communication effective found that modern technology such as Internet percentage 93.6 and accessory percentage 88.8 , suitable communication applied organization development had to be help more convenience of operation percentage 90.4 and real useful percentage 79.2 related with Pinyo Satorn (2010) said that communication to be success or achieve had to understanding. Both se de had the same recognition and attitude so when implement the communication system should focus on suitable job and useful in order to create convenience for organization related with research of Peera Jeerasopon (1992) said that communication factor was the specified successful and failure of sending as choosing receipt process

5. Reward should have principle or regulation of giving reward to officer who was spirit, patient, responsible for percentage 81.6 giving reward was motivation and award impacted organization had development, it become person who invented to action in their activity more percentage 100 and officer concentrated behavior to be success percentage 85.6. Reward system should be promotion pattern and increased suitable salary together percentage 100 , both inward and outward reward impacted the officer feel anxious to operate and morale percentage 50.4 and outward reward was life wealth percentage 41.6, inward reward was best motivation effected officer who had the morale and spirit to develop organization more effective percentage 10" related with research of Tanawan Tungsintupsiri (2007) said that there was high operation level and production more. Managing level could penetrate deeply to motivated theory in order to design motivated program and efficiency for efficiency for officer who must to understand in suitable reward system so whatever inward or outward should be together because both of its were important, reward was the feeling while was wealth so they should keep its together

6. Measurement and assessment impacted operation of service and organization development of booting potential to work of organization to be high percentage 96 and to motivate the officers developed by themselves percentage 84.8 , assessment was sensitive to current situation changes and measurement system change found that service of function was not necessary to competitive with other organization so it had not the tool or assessment percentage 63.2 and working feature had not focus the profit so it was not necessary to have 
the modern measurement and assessment tool percentage 49.6, the best measurement and assessment for the officer who was to development of organization 's service, it become learning and management percentage 100 and made potential of organization percentage 87.5 taking information technology applied with measurement and assessment impacted the organization development found that it knew the guide of organization development next percentage 100 and able to see the potent level in service percentage 87.2 so the result related with theory of Crosby (1986) said that the system arrangement by quality measurement was clear that it was the operation indicator of total quality management reward guideline to operate organization so it should had the quality of who should get reward obviously.

7. Teamwork, organization paid attention with teamwork found that sub-district administrative organization was service, team was important to service percentage 91.2 , teamwork development guideline had potential and impacted the organization development by specified meeting away percentage 88.8

\section{Suggestion}

1. Administrators should give importance to building engagement with the organization. Show love and care and are dedicated to the organization

2. Administrators should increase morale and encouragement Increase progress in work, training, support for further education for personnel equally, allow employees to do the best

3. Administrators should take into account the appropriateness of the work of the operational level staff. It is a job that matches the knowledge, ability and ability for the employees to have clear goals. By having knowledge Increased ability Is a good way to work

4. Employees should be aware of the promotion of engagement with the organization. To increase work efficiency Creating a good feeling for the organization to love Faith, feeling and being one with the organization And believe in the goals of the organization

\section{Acknowledgement}

The author would like to thank College of Innovation and Management Suan Sunandha Rajabhat University (www.ssru.ac.th), Bangkok, Thailand for financial support.

\section{References:}

Baimyrzaeva, M. (2012). Institutional reforms in the public sector: What did we learn? Bingley, UK: Emerald Group Pub Ltd.

Borins, S. (2002). New public management, North American style. In K. Mclaughlin, S. P. Osborne, \& E. Ferlie (Eds.), New public management: Current trends and future prospects. New York, NY: Routledge.

Cheyjanya,P, (1998). Key concepts in communication. Bangkok; Yellow Printing.

Haque, S. M. (2007). Theory and practice of public administration in Southeast Asia: Traditions, directions, and impacts. International Journal of Public Administration, 30: 1297-1326.

Jerasopon, P. (1992). Communication theory. Lecture of main subject and communication theory. Sukhothai Thammathirat University

Mongkol, K. (2012). Globalizing new public management: A pilot study from Thailand. Research Journal of Business Management, 6(1), 19-29. 


\section{FACTORS AFFECTING QUALITY MANAGEMENT}

Naranan,C. \& Trakulsa, P. (2013). Administration of sub-district administrative organization Thaloung sib-district, Muang district Phichit province. Thesis Master of Public Administration, major public policy, Naresuan University.

Painter, M. (2006). Thaksinisation or managerialism? Reforming the Thai bureaucracy. Journal of Contemporary Asia, 36(1), 26-47.

Phumdara, T. (2018). Public Participation in the Local Development Plan of Phromphiram SubDistrict, Phromphiram District, Phitsanulok Province.

Pollitt, C., \& Bouckaert, G. (2011). Public management reform a comparative analysis: New public management, governance, and the neo-Weberian state. New York, NY: Oxford University Press.

Satorn, P. (2010). Education administration. Bangkok: Khurusapha Printing.

Suwandej, N. (2015). Factors Influencing Total Quality Management. Procedia - Social and Behavioral Sciences, 197, 2215-2222

Tanaporn, C, \& Sadudee, M, (2000). The management participation in environment management to contribute learning in school for opportunity expansion. Phitsanulok Primary Education Service Area Officer 3. Master of Education Program in Curriculum and Instruction, Burapha University.

O6 June 2019

Paper accepted for publishing

O2 August 2019

Paper published online

08 August 2019 